Research article

Open Access

\title{
Expression of hypoxia-inducible factor-1 $\alpha$ and cell cycle proteins in invasive breast cancer are estrogen receptor related
}

\author{
Reinhard Bos ${ }^{1}$, Paul J van Diest ${ }^{2}$, Petra van der Groep ${ }^{2}$, Avi Shvarts ${ }^{2}$, Astrid E Greijer ${ }^{1}$ and \\ Elsken van der Wall3
}

\author{
1Department of Pathology, VU University medical center, Amsterdam, The Netherlands \\ ${ }^{2}$ Department of Pathology, University Medical Center Utrecht, Utrecht, The Netherlands \\ ${ }^{3}$ Division of Internal Medicine and Dermatology, University Medical Center Utrecht, Utrecht, The Netherlands \\ Corresponding author: Elsken van der Wall, e.vanderwall@azu.nl
}

Received: 16 Mar 2004 Accepted: 12 May 2004 Published: 9 Jun 2004

Breast Cancer Res 2004, 6:R450-R459 (DOI 10.1186/bcr813)

(C) 2004 Bos et al.; licensee BioMed Central Ltd. This is an Open Access article: verbatim copying and redistribution of this article are permitted in all media for any purpose, provided this notice is preserved along with the article's original URL.

\begin{abstract}
Background The transcription factor hypoxia-inducible factor-1 (HIF-1) is a key regulator of the cellular response to hypoxia. Previous studies showed that concentrations of its subunit HIF$1 \alpha$, as a surrogate for HIF- 1 activity, are increased during breast carcinogenesis and can independently predict prognosis in breast cancer. During carcinogenesis, the cell cycle is progressively deregulated, and proliferation rate is a strong prognostic factor in breast cancer. In this study we undertook a detailed evaluation of the relationships between HIF- $1 \alpha$ and cell cycle-associated proteins.
\end{abstract}

Methods In a representative estrogen receptor (ER) group of 150 breast cancers, the expression of HIF-1 $\alpha$, vascular endothelial growth factor, the ER, HER-2/neu, Ki-67, cyclin A, cyclin $D_{1}, \quad p 21, p 53$, and $B c l-2$ was investigated by immunohistochemistry.

Results High concentrations ( $5 \%$ or more) of HIF- $1 \alpha$ were associated with increased proliferation as shown by positive correlations with Ki-67 $(P<0.001)$ and the late S-G2-phase protein cyclin $\mathrm{A}(P<0.001)$, but not with the $\mathrm{G} 1$-phase protein cyclin $D_{1}$. High HIF-1 $\alpha$ concentrations were also strongly associated with p53 positivity $(P<0.001)$ and loss of Bcl-2 expression $(P=0.013)$. No association was found between $\mathrm{p} 21$ and HIF-1 $\alpha(P=0.105)$ in the whole group of patients. However, the subgroup of ER-positive cancers was characterized by a strong positive association between HIF-1 $\alpha$ and p21 $(P=0.023)$, and HIF-1 $\alpha$ lacked any relation with proliferation.

Conclusion HIF-1 $\alpha$ overexpression is associated with increased proliferation, which might explain the adverse prognostic impact of increased concentrations of HIF- $1 \alpha$ in invasive breast cancer. In ER-positive tumors, HIF-1 $\alpha$ is associated with p21 but not against proliferation. This shows the importance of further functional analysis to unravel the role of HIF-1 in late cell cycle progression, and the link between HIF$1, \mathrm{p} 21$, and ER.

Keywords: Bcl-2, breast cancer, estrogen receptor, hypoxia-inducible factor-1 $\alpha$, p53

\section{Introduction}

Hypoxia is an important cellular stressor that triggers a survival program by which cells attempt to adapt to the new environment. This primarily involves adaptation of metabolism and/or stimulation of oxygen delivery. These cell-rescuing mechanisms can be conducted rapidly by a transcription factor that reacts to hypoxic conditions, the hypoxia-inducible factor-1 (HIF-1) [1]. HIF-1 stimulates processes such as angiogenesis, glycolysis and erythropoiesis [2] by activating genes that are responsible for these processes. The HIF-1 complex consists of two subu- nits, HIF- $1 \alpha$ and HIF-1 $\beta$. Protein concentrations of HIF- $1 \alpha$ depend on the cellular oxygen concentration [3,4]. During normoxia the HIF-1 $\alpha$ protein has a very short half-life owing to its continuous Von Hippel-Lindau (VHL) protein-mediated ubiquitination, which results in low protein concentrations in the cytoplasm. Hypoxia results in stabilization of the HIF-1 $\alpha$ protein and translocation of the HIF-1 complex to the nucleus. In the nucleus HIF-1 binds to DNA of the consensus sequence 5'-RCGTG-3', the so-called hypoxia response elements in the promoters of target genes [5]. In this way HIF-1 allows the cell to adapt metabolism, 
increases $\mathrm{O}_{2}$ delivery and stimulates cell survival [6]. Besides hypoxia, HIF-1 can be upregulated by loss of the tumor suppressor genes PTEN (phosphatase and tensin homolog deleted on chromosome ten) [7] and loss of p53 [8], and by the overexpression of oncogenes such as HER2/neu [9].

Cancer cells are able to survive and proliferate in extreme microenvironmental circumstances and show changes in oncogenes and tumor suppressor genes. Hypoxia and HIF1 have been implicated in carcinogenesis and in clinical behavior of tumors. Upregulation of HIF-1 $\alpha$ was noted during breast carcinogenesis [10], especially in the poorly differentiated pathway. Hypoxia is related to poor response to therapy in various cancer types. In invasive breast cancer, high HIF- $1 \alpha$ concentrations were associated with poor survival in lymph node-negative patients [11]. As prognosis in breast cancer is closely related to proliferation rate [12], and poorly differentiated tumors usually exhibit high proliferation and HIF- $1 \alpha$ overexpression, the prognostic value of HIF-1 $\alpha$ might well be explained by a close association between HIF- $1 \alpha$ and proliferation.

Proliferation is under the control of many proteins involved in cell cycle regulation. We proposed that HIF-1, as a master regulator for surviving hypoxia, might interact with such cell cycle-related proteins. We therefore investigated whether concentrations of HIF- $1 \alpha$ were associated with aberrant expression of cell cycle proteins in human breast cancer. As a result, we report here that high concentrations of HIF- $1 \alpha$ are associated with overexpression of p53 and markers of proliferation during the late S-G2 phase of the cell cycle. In the subgroup of estrogen receptor (ER)-positive cancers only a positive association between HIF- $1 \alpha$ and p21 was noticed. Probably, in ER-positive cases, p21 causes cell cycle arrest as a response to increased HIF-1 $\alpha$ concentrations.

\section{Materials and methods Patients}

A representative and previously described group of 150 stage I/II breast cancer patients, diagnosed between 1985 and 1993 at the VU University Medical Center, Amsterdam, The Netherlands, was used [11]. By 'representative' we mean that tumor size, distribution of histological subtypes and lymph node status were as expected in a random group of stage I/II patients. Breast-conserving therapy or modified radical mastectomy were the applied surgical procedures for the primary tumors, and axillary dissection including at least levels I and II was performed for all patients. All surgical specimens were directly fixed in neutral $4 \%$ buffered formaldehyde.

All invasive breast carcinomas were histologically classified according to $\mathrm{WHO}$ criteria as one of the following: ductal
( $n=129)$, lobular $(n=11)$, mucinous $(n=4)$, tubular $(n=$ $3)$, cribriform $(n=1)$, medullary $(n=1)$, or metaplastic $(n=$ 1). Tumors were graded in accordance with the criteria of Elston [13] as grade I $(n=35)$, grade II $(n=49)$, or grade III $(n=66)$. The mean age at the time of diagnosis was 60 years (range 30 to 86). The mean tumor diameter was 2.6 $\mathrm{cm}$, ranging from 0.7 to $7.0 \mathrm{~cm}$ (according to the TNM [tumor, node, metastases] system: $45 \mathrm{~T}_{1}, 94 \mathrm{~T}_{2}$, and 11 $\mathrm{T}_{3}$ ). Locally advanced breast cancers (TNM stage III) were excluded. The group included 81 (54\%) lymph node-negative and $69(46 \%)$ lymph node-positive patients. None of the patients received preoperative chemotherapy, hormonal therapy or radiotherapy.

\section{Immunohistochemistry}

Paraffin-embedded tumor tissue was derived from the archives of the Department of Pathology of the VU University Medical Center. Anonymous use of redundant tumor material for research purposes is part of the standard treatment agreement with patients in our hospital [14]. Immunohistochemistry was performed on sections $4 \mu \mathrm{m}$ thick. After deparaffination and rehydration, sections were immersed for $30 \mathrm{~min}$ in methanol containing $0.3 \%$ hydrogen peroxide to block endogenous peroxidase activity. For assessment of HIF-1 $\alpha$ the catalyzed signal amplification system (Dako, Glostrup, Denmark) was used as described previously [11]. All slides, except for HER-2/neu, were pretreated with a citrate buffer $(10 \mathrm{mM}, \mathrm{pH}$ 6.0) for antigen retrieval by heating the slides in either a microwave oven or an autoclave (for details see Table 1 ).

After cooling down and preincubation with normal serum of the species of the secondary antibody, the primary antibodies were incubated as described in Table 1. For recognition of vascular endothelial growth factor (VEGF), a rabbit polyclonal antibody was used, which was detected with a pig anti-rabbit antibody (Dako). Subsequently, slides were incubated for 30 min with biotinylated secondary antibodies, followed by incubation for $1 \mathrm{~h}$ with 1:200 streptavidinbiotinylated horseradish peroxidase complex (Dako). For $\mathrm{Bcl}-2$ and $\mathrm{p} 21$ staining, a biotinyl-tyramide enhancing step was introduced [15]. After a $30 \mathrm{~min}$ incubation of 1:1000 (instead of 1:200) streptavidin-biotinylated horseradish peroxidase complex, slides were incubated for $10 \mathrm{~min}$ with 1:1000 diluted biotinyl-tyramide solution with $0.01 \%$ hydrogen peroxide in phosphate-buffered saline, followed by incubation for $30 \mathrm{~min}$ with 1:200 streptavidin-biotinylated horseradish peroxidase complex. In all cases 3, 3diaminobenzidine was used as chromagen and hematoxylin as counterstaining. Positive controls consisted of known immunoreactive carcinomas (VEGF, HIF-1 $\alpha$, ER, p53, cyclin $\mathrm{D}_{1}, \mathrm{p} 21, \mathrm{HER}-2 /$ neu) or tonsil tissue (Ki-67, Bcl-2, cyclin A). Negative controls were obtained by omission of the primary antibodies from the staining procedure. 
Table 1

\begin{tabular}{|c|c|c|c|c|c|}
\hline Antibody & Company & Dilution & Incubation & Antigen retrieval & Detection \\
\hline Ki-67 & Dako & $1: 40$ & $\mathrm{o} / \mathrm{n}, 4^{\circ} \mathrm{C}$ & MW & $\mathrm{ABC}$ \\
\hline Cyclin A & Novocastra & $1: 100$ & $\mathrm{o} / \mathrm{n}, 4^{\circ} \mathrm{C}$ & Autoclave & $\mathrm{ABC}$ \\
\hline Cyclin $D_{1}$ & Neomarkers & $1: 400$ & $\mathrm{o} / \mathrm{n}, 4^{\circ} \mathrm{C}$ & Autoclave & $\mathrm{ABC}$ \\
\hline p21 & Pharmingen & $1: 500$ & $\mathrm{o} / \mathrm{n}, 4^{\circ} \mathrm{C}$ & Autoclave & ABC-BT \\
\hline p53 & DAKO & $1: 50$ & $\mathrm{o} / \mathrm{n}, 4^{\circ} \mathrm{C}$ & $\mathrm{MW}$ & $\mathrm{ABC}$ \\
\hline $\mathrm{Bcl}-2$ & DAKO & $1: 50$ & $\mathrm{o} / \mathrm{n}, 4^{\circ} \mathrm{C}$ & Autoclave & ABC-BT \\
\hline ER & DAKO & $1: 50$ & $\mathrm{o} / \mathrm{n}, 4^{\circ} \mathrm{C}$ & Autoclave & $\mathrm{ABC}$ \\
\hline VEGF & R\&D systems & $1: 40$ & $\mathrm{o} / \mathrm{n}, 4^{\circ} \mathrm{C}$ & Autoclave & $\mathrm{ABC}$ \\
\hline HIF- $1 \alpha$ & Abcam & $1: 500$ & $1 \mathrm{~h}, 20^{\circ} \mathrm{C}$ & Waterbath & CSA kit \\
\hline HER-2/neu & M v/d Vijver & $1: 10,000$ & $\mathrm{o} / \mathrm{n}, 4^{\circ} \mathrm{C}$ & None & $\mathrm{ABC}$ \\
\hline
\end{tabular}

Autoclave, autoclave for 20 min at $120^{\circ} \mathrm{C}$; ABC, avidin-biotinyl complex; ABC-BT, biotinyl-tyramide enhancement; Mv/d Vijver, Dr M van der Vijver, Dutch Cancer Institute, Amsterdam, The Netherlands; MW, microwave in citrate buffer pH 6.0 for 10 min near to boiling; o/n, overnight; Waterbath, $45 \mathrm{~min}$ at $95^{\circ} \mathrm{C}$.

\section{Quantification}

For all cell cycle biomarkers, except Bcl-2, the percentage of positively stained nuclei of invasive tumor cells was scored blind by one experienced observer (PJvD). ER status was determined by the Histoscore, taking 100 or more as positive. HIF- $1 \alpha$ staining was considered positive only when there was homogeneously dark nuclear staining; cytoplasmic staining was ignored. Cytoplasmic staining for Bcl-2 in invasive breast cancer epithelium was compared with adjacent normal breast tissue and scored as negative when absent, and as weak or strong when intensity was diminished or increased, respectively, compared with adjacent normal tissue. Cytoplasmic VEGF expression was assessed as moderate or strong.

\section{Statistical methods}

For statistical analysis with SPSS for Windows version 9.0.1., 1999 (SPSS Inc., Chicago, IL), the nonparametric $\chi^{2}$ was used to evaluate correlations between HIF- $1 \alpha$ and cell cycle-associated proteins. For the cell cycle-related proteins we used traditional cutoff values [16] (as shown in Table 2), and for HIF-1 $\alpha 5 \%$ was used as the cutoff value as described previously [11]. Parametric tests and correlation tests using the continuous data were also performed, but these yielded similar results and have therefore not been described to keep description of the statistical results as succinct as possible. Two-sided $P$ values below 0.050 were regarded as significant.

\section{Results}

\section{Whole group}

Analyzing the whole group of patients $(n=150)$, there were significant and positive associations between HIF-1 $\alpha$ and
Ki-67 $(P<0.001)$, cyclin A $(P<0.001)$, and p53 $(P<$ 0.001 ) (Table 2). A positive trend between high concentrations of HIF-1 $\alpha$ and expression of p21 ( $P=0.105)$ was noticed, and there was a significant inverse association between Bcl-2 ( $P=0.025)$ and HIF-1 $\alpha$ expression. No association between HIF- $1 \alpha$ and cyclin $D_{1}$ was found. In addition, both ER positivity and overexpression of p21 were positively associated with overexpression of cyclin $\mathrm{D}_{1}(P<$ 0.001 ) in the whole group of patients.

\section{ER subgroups}

Interestingly, subgroup analysis of ER-positive cancers ( $n=$ 52) revealed different associations (Table 3 ). Only p21 positivity was significantly associated with high concentrations of HIF-1 $\alpha(P=0.023)$. No associations for HIF-1 $\alpha$ were found with $\mathrm{Ki}-67$, cyclins $A$ and $\mathrm{D}_{1}, \mathrm{p} 53$, and $\mathrm{Bcl}-2$. In this subgroup, p21 was positively associated with cyclin $D_{1}$ $(P<0.001)$ but not with p53. In contrast, the subgroup of ER-negative cancers $(n=98)$ showed strongly significant positive associations between HIF- $1 \alpha$ on the one hand and Ki-67 $(P<0.001)$, cyclin A $(P<0.001)$, and p53 $(P=$ $0.003)$ on the other. Again, loss of Bcl-2 ( $P=0.048)$ was significantly negatively associated with high concentrations of HIF- $1 \alpha$, and no association between HIF-1 $\alpha$, p21, and cyclin $D_{1}$ was found. The striking difference in biomarker expression between the ER-positive and ER-negative subgroups led us to test further whether this was associated with proliferation or with HIF-1 $\alpha$. In the ER-positive subgroup HER-2/neu-positivity was associated with high concentrations of HIF- $1 \alpha(P=0.035)$, but no association was found between HIF-1 $\alpha$, p53, and VEGF. Further, in this subgroup we observed low ER expression in HIF-1 $\alpha$-positive regions. In the ER-negative subgroup strong VEGF 
Table 2

\begin{tabular}{|c|c|c|c|c|}
\hline \multirow[t]{2}{*}{ Protein } & \multirow[t]{2}{*}{ Cutoff value } & \multicolumn{2}{|c|}{ Concentration of HIF- $1 \alpha$} & \multirow[t]{2}{*}{$P\left(\chi^{2}\right)$} \\
\hline & & $<5 \%$ & $\geq 5 \%$ & \\
\hline \multirow[t]{2}{*}{ Ki-67 } & $\leq 10 \%$ & 58 & 13 & $<0.001$ \\
\hline & $>10 \%$ & 41 & 38 & \\
\hline \multirow[t]{2}{*}{ Cyclin A } & $\leq 10 \%$ & 67 & 19 & $<0.001$ \\
\hline & $>10 \%$ & 31 & 32 & \\
\hline \multirow[t]{2}{*}{ Cyclin $D_{1}$} & $\leq 10 \%$ & 80 & 44 & 0.402 \\
\hline & $>10 \%$ & 19 & 7 & \\
\hline \multirow[t]{2}{*}{ p21 } & $\leq 10 \%$ & 89 & 41 & 0.105 \\
\hline & $>10 \%$ & 10 & 10 & \\
\hline \multirow[t]{2}{*}{ p53 } & $\leq 25 \%$ & 89 & 35 & $<0.001$ \\
\hline & $>25 \%$ & 10 & 16 & \\
\hline \multirow[t]{3}{*}{$\mathrm{Bcl}-2$} & Negative & 4 & 5 & 0.025 \\
\hline & Moderate & 35 & 26 & \\
\hline & Strong & 60 & 19 & \\
\hline
\end{tabular}

HIF, hypoxia-inducible factor.

expression $(P=0.007)$, p53 accumulation $(P=0.003)$, and HER-2/neu-positivity $(P=0.003)$ were all positively associated with high concentrations of HIF-1 $\alpha$.

\section{p53 subgroups}

To exclude the possibility that the data for the ER subgroups were dependent on p53 status, we also performed subgroup analysis based on p53 status (Table 4). In short, the subgroup assumed to be 'wild-type' p53 was characterized by different associations from the subgroup of ERpositive cases.

\section{Lymph node status subgroups}

Because in our former study we found an independent prognostic value for HIF-1 $\alpha$ only in lymph node-negative breast cancers, we analyzed the subgroups of lymph nodenegative $(n=81)$ and lymph node-positive cases $(n=69)$ separately (Table 5). Positive significant associations were found in the subgroup of lymph node-negative cancers between HIF- $1 \alpha$ and Ki-67 $(P<0.001)$, cyclin A $(P<$ $0.001)$, p21 $(P=0.049)$, and p53 $(P=0.001)$. Also in this subgroup Bcl-2 $(P=0.008)$ was significantly inversely associated with HIF- $1 \alpha$. No association was found for cyclin $D_{1}$. In the subgroup of lymph node-positive cancers, Ki$67(P=0.035)$ and p53 $(P=0.042)$ revealed a positive association with HIF- $1 \alpha$. No relation with HIF- $1 \alpha$ was found for cyclins $A$ and $D_{1}$, p21, and Bcl-2.

\section{Ductal type subgroup}

To exclude confounding mechanisms based on the mixed group of different types of breast cancer, we also performed the statistical analysis described above on the subgroup of ductal type of invasive breast cancers $(n=129)$, as shown in Tables 6 and 7. In short, the same associations were found as described for the group of 150 patients.

\section{Discussion}

In this study we found positive associations between HIF$1 \alpha$ and the cell cycle-related proteins cyclin $\mathrm{A}, \mathrm{Ki}-67$, and p53 in invasive human breast cancers. These associations were most evident in the lymph node-negative cases and might therefore contribute to the poor prognosis of HIF- $1 \alpha$ positive cancers described previously [11]. Further, the ER subgroups showed differential expression of biomarkers, suggesting an interaction between HIF-1 and ER.

In general, the expression of cyclin A and $\mathrm{Ki}-67$ indicates that cells are in the $S$ or $G 2$ phase. Cyclin A expression is stimulated by the protein-tyrosine phosphatase cdc25A [17] and is associated with undifferentiated and ER-negative breast tumors heralding poor prognosis $[18,19]$. It is common to use protein concentrations of Ki-67 as a proliferation marker although its function is unknown; it is present at highest concentration in the $S$ phase but also in the G1-G2 phase [20]. Like cyclin A, Ki-67 overexpression denotes a high proliferation rate and thus poor prognosis. Our data show that high concentrations of HIF- $1 \alpha$ are associated with high concentrations of cyclin A and Ki-67 as markers of proliferation.

The association of HIF-1 with proliferation has been noted before [10], but it is still not fully understood $[21,22]$. The main question is whether HIF-1 is acting on, or is a reaction to, tumor proliferation. The latter mechanism assumes that unorganized rapidly growing tumors will outgrow their own vasculature, leading to a lack of oxygen supply, necessitating adaptation by switching to anaerobic metabolism and induction of angiogenesis. Because HIF-1 has a crucial role in these latter processes, it could be postulated that rapidly proliferating tumors need HIF-1. In this light the association between HIF-1 and proliferation is more or less epigenetic or due to tumor necrosis. According to the former mechanism, primary HIF-1 overexpression might also lead to tumor proliferation. One argument for this hypothesis is based on the observation that HIF- $1 \alpha$ expression is not restricted to necrotic tumor areas. Another argument might be the influence of oncogenes (such as HER-2/neu or Bcl6), tumor suppressor genes (such as von Hippel-Lindau [tumor suppressor gene] protein [pVHL] or PTEN), or growth factors (such as IGF-2) on the protein concentrations of HIF-1 $\alpha$ [7,9,23-26]. These tumorigenic mechanisms also stimulate proliferation. In addition, the recent demonstration that pulmonary artery fibroblasts, when 
Table 3

\begin{tabular}{|c|c|c|c|c|c|c|c|}
\hline \multirow[t]{3}{*}{ Protein } & \multirow[t]{3}{*}{ Cutoff value } & \multicolumn{3}{|c|}{ ER-positive } & \multicolumn{3}{|c|}{ ER-negative } \\
\hline & & \multicolumn{2}{|c|}{$\mathrm{HIF}-1 \alpha$} & \multirow[t]{2}{*}{$P\left(\chi^{2}\right)$} & \multicolumn{2}{|c|}{ HIF-1 $\alpha$} & \multirow[t]{2}{*}{$P\left(\chi^{2}\right)$} \\
\hline & & $<5 \%$ & $\geq 5 \%$ & & $<5 \%$ & $\geq 5 \%$ & \\
\hline \multirow[t]{2}{*}{ Ki-67 } & $\leq 10 \%$ & 24 & 7 & 0.624 & 34 & 6 & $<0.001$ \\
\hline & $>10 \%$ & 15 & 7 & & 26 & 32 & \\
\hline \multirow[t]{2}{*}{ Cyclin A } & $\leq 10 \%$ & 28 & 9 & 0.756 & 39 & 10 & $<0.001$ \\
\hline & $>10 \%$ & 10 & 4 & & 21 & 28 & \\
\hline \multirow[t]{2}{*}{ Cyclin $D_{1}$} & $\leq 10 \%$ & 25 & 9 & 0.736 & 55 & 35 & 0.938 \\
\hline & $>10 \%$ & 14 & 4 & & 5 & 3 & \\
\hline \multirow[t]{2}{*}{$\mathrm{p} 21$} & $\leq 10 \%$ & 33 & 7 & 0.023 & 56 & 34 & 0.497 \\
\hline & $>10 \%$ & 6 & 6 & & 4 & 4 & \\
\hline \multirow[t]{2}{*}{ p53 } & $\leq 25 \%$ & 36 & 11 & 0.415 & 53 & 24 & 0.003 \\
\hline & $>25 \%$ & 3 & 2 & & 7 & 14 & \\
\hline \multirow[t]{3}{*}{$\mathrm{Bcl}-2$} & Negative & 0 & 0 & 0.609 & 4 & 5 & 0.048 \\
\hline & Moderate & 12 & 5 & & 23 & 21 & \\
\hline & Strong & 27 & 8 & & 33 & 11 & \\
\hline \multirow[t]{2}{*}{ VEGF } & Weak & 8 & 2 & 0.685 & 21 & 4 & 0.007 \\
\hline & Strong & 31 & 11 & & 39 & 34 & \\
\hline \multirow[t]{2}{*}{ HER-2/neu } & Negative & 36 & 9 & 0.035 & 55 & 26 & 0.003 \\
\hline & Positive & 3 & 4 & & 5 & 12 & \\
\hline
\end{tabular}

ER, estrogen receptor; HIF, hypoxia-inducible factor; VEGF, vascular endothelial growth factor.

exposed to hypoxia, stimulate the proliferation of adjacent pulmonary artery smooth muscle cells by means of hypoxiaregulated genes indicates a stimulating role for HIF-1 in the cell cycle machinery [27].

In contrast, recent work from Goda and colleagues [28] showed in two different primary differentiated cell types that HIF-1 is necessary for the induction of growth arrest during hypoxia. HIF-1 alters the cell cycle during hypoxia by increasing the concentrations of cyclin-dependent kinase inhibitors p21 and p27. In addition, hypophosphorylation of retinoblastoma proteins is HIF-1 dependent. Goda and colleagues [28] also showed that cells lacking the HIF-1 $\alpha$ gene had an increased progression into $S$ phase. These in vitro data are logical in physiologic circumstances but do not comply with our observations in human cancers. Thus, it is difficult to say whether these mechanisms also occur in human breast cancer. More possibly, it might be postulated that cancer cells have lost control over the cell cycle and its potential interplay with HIF-1 $\alpha$.
Subgroup analyses based on ER status revealed that only in ER-positive cases positivity for p21 was associated with high concentrations of HIF- $1 \alpha$, without correlation between HIF-1 and proliferation. This points to an intact feedback loop in ER-expressing cells in which p21 might cause cell cycle arrest as a response to increased HIF-1 $\alpha$ concentration, which might be regulated by cyclin $D_{1}$ [29]. In contrast, in ER-negative cases, a positive association between HIF1 on the one hand and Ki-67, cyclin A, p53, and loss of Bcl2 on the other was noted. Apparently, the p21 feedback loop is not functional in ER-negative cells. In addition, in the ER-positive cases no association for HIF- $\alpha$ with VEGF and p53 could be demonstrated, which was opposite to the observation in the ER-negative subgroup. These findings suggest that the different associations in both ER subgroups cannot be attributed only to a different proliferation rate. We excluded the option that the p53 status might be the underlying cause for these differences, as shown in Table 4. It is therefore tempting to suggest that these differences might be caused by an interaction between HIF-1 
Table 4

\begin{tabular}{|c|c|c|c|c|c|c|c|}
\hline \multirow[t]{3}{*}{ Protein } & \multirow[t]{3}{*}{ Cutoff value } & \multicolumn{3}{|c|}{ 'Wild type' p53 } & \multicolumn{3}{|c|}{ 'Mutated' p53 } \\
\hline & & \multicolumn{2}{|c|}{ HIF-1 $\alpha$} & \multirow[t]{2}{*}{$P\left(\chi^{2}\right)$} & \multicolumn{2}{|c|}{ HIF-1 $\alpha$} & \multirow[t]{2}{*}{$P\left(\chi^{2}\right)$} \\
\hline & & $<5 \%$ & $\geq 5 \%$ & & $<5 \%$ & $\geq 5 \%$ & \\
\hline \multirow[t]{2}{*}{ Ki-67 } & $\leq 10 \%$ & 55 & 12 & 0.006 & 3 & 1 & 0.264 \\
\hline & $>10 \%$ & 34 & 23 & & 7 & 15 & \\
\hline \multirow[t]{2}{*}{ Cyclin A } & $\leq 10 \%$ & 62 & 15 & 0.004 & 5 & 4 & 0.192 \\
\hline & $>10 \%$ & 26 & 20 & & 5 & 12 & \\
\hline \multirow[t]{2}{*}{ Cyclin $D_{1}$} & $\leq 10 \%$ & 71 & 31 & 0.248 & 9 & 13 & 1.00 \\
\hline & $>10 \%$ & 18 & 4 & & 1 & 3 & \\
\hline \multirow[t]{2}{*}{ p21 } & $\leq 10 \%$ & 80 & 28 & 0.139 & 9 & 13 & 1.00 \\
\hline & $>10 \%$ & 9 & 7 & & 1 & 3 & \\
\hline \multirow[t]{3}{*}{$\mathrm{Bcl}-2$} & Negative & 3 & 3 & 0.273 & 1 & 2 & 0.132 \\
\hline & Moderate & 31 & 15 & & 4 & 11 & \\
\hline & Strong & 55 & 17 & & 5 & 2 & \\
\hline \multirow[t]{2}{*}{ VEGF } & Weak & 28 & 5 & 0.051 & 1 & 1 & 1.00 \\
\hline & Strong & 61 & 30 & & 9 & 15 & \\
\hline \multirow[t]{2}{*}{ HER-2/neu } & Negative & 82 & 27 & 0.021 & 9 & 8 & 0.037 \\
\hline & Positive & 7 & 8 & & 1 & 8 & \\
\hline
\end{tabular}

aFisher Exact Test when appropriate. HIF, hypoxia-inducible factor; VEGF, vascular endothelial growth factor; WT-p53, probably wild type p53; Mp53, probably mutated p53.

Table 5

Association of HIF-1 $\alpha$ with cell cycle-related proteins in lymph node-negative $(n=81)$ and lymph node-positive $(n=69)$ breast cancers

\begin{tabular}{|c|c|c|c|c|c|c|c|}
\hline \multirow[t]{3}{*}{ Protein } & \multirow[t]{3}{*}{ Cutoff value } & \multicolumn{3}{|c|}{ Lymph node-negative } & \multicolumn{3}{|c|}{ Lymph node-positive } \\
\hline & & \multicolumn{2}{|c|}{ HIF-1 $\alpha$} & \multirow[t]{2}{*}{$P\left(\chi^{2}\right)$} & \multicolumn{2}{|c|}{ HIF-1 $\alpha$} & \multirow[t]{2}{*}{$P\left(\chi^{2}\right)$} \\
\hline & & $<5 \%$ & $\geq 5 \%$ & & $<5 \%$ & $\geq 5 \%$ & \\
\hline \multirow[t]{2}{*}{ Ki-67 } & $\leq 10 \%$ & 36 & 9 & $<0.001$ & 22 & 4 & 0.035 \\
\hline & $>10 \%$ & 15 & 21 & & 26 & 17 & \\
\hline \multirow[t]{2}{*}{ Cyclin A } & $\leq 10 \%$ & 40 & 10 & $<0.001$ & 27 & 9 & 0.305 \\
\hline & $>10 \%$ & 10 & 20 & & 21 & 12 & \\
\hline \multirow[t]{2}{*}{ Cyclin $D_{1}$} & $\leq 10 \%$ & 40 & 25 & 0.593 & 40 & 19 & 0.438 \\
\hline & $>10 \%$ & 11 & 5 & & 8 & 2 & \\
\hline \multirow[t]{2}{*}{ p21 } & $\leq 10 \%$ & 47 & 23 & 0.049 & 42 & 18 & 0.839 \\
\hline & $>10 \%$ & 4 & 7 & & 6 & 3 & \\
\hline \multirow[t]{2}{*}{ p53 } & $\leq 25 \%$ & 47 & 21 & 0.009 & 42 & 14 & 0.042 \\
\hline & $>25 \%$ & 4 & 9 & & 6 & 7 & \\
\hline \multirow[t]{3}{*}{$\mathrm{Bcl}-2$} & Negative & 0 & 3 & 0.008 & 4 & 2 & 0.459 \\
\hline & Moderate & 17 & 15 & & 18 & 11 & \\
\hline & Strong & 34 & 11 & & 26 & 8 & \\
\hline
\end{tabular}

HIF, hypoxia-inducible factor. 
Table 6

\begin{tabular}{|c|c|c|c|c|}
\hline \multirow[t]{2}{*}{ Protein } & \multirow[t]{2}{*}{ Cutoff value } & \multicolumn{2}{|c|}{ Concentration of HIF- $1 \alpha$} & \multirow[t]{2}{*}{$P\left(\chi^{2}\right)$} \\
\hline & & $<5 \%$ & $\geq 5 \%$ & \\
\hline \multirow[t]{2}{*}{$\mathrm{Ki}-67$} & $\leq 10 \%$ & 44 & 11 & 0.001 \\
\hline & $>10 \%$ & 39 & 35 & \\
\hline \multirow[t]{2}{*}{ Cyclin A } & $\leq 10 \%$ & 52 & 16 & 0.002 \\
\hline & $>10 \%$ & 30 & 30 & \\
\hline \multirow[t]{2}{*}{ Cyclin $D_{1}$} & $\leq 10 \%$ & 67 & 39 & 0.564 \\
\hline & $>10 \%$ & 16 & 7 & \\
\hline \multirow[t]{2}{*}{$\mathrm{p} 21$} & $\leq 10 \%$ & 75 & 36 & 0.057 \\
\hline & $>10 \%$ & 8 & 10 & \\
\hline \multirow[t]{2}{*}{ p53 } & $\leq 25 \%$ & 68 & 25 & 0.001 \\
\hline & $>25 \%$ & 15 & 21 & \\
\hline \multirow[t]{3}{*}{$\mathrm{Bcl}-2$} & Negative & 4 & 5 & 0.042 \\
\hline & Moderate & 29 & 23 & \\
\hline & Strong & 50 & 17 & \\
\hline
\end{tabular}

HIF, hypoxia-inducible factor.

and ER. Little is known about the interaction between HIF1 and ER, but an almost significant positive association was found in endometrial cancer [30] but not in breast cancer $[11,31]$. In prostate cancer the presence of the androgen receptor seems necessary to potentiate the angiogenic effects of HIF- $1 \alpha$, although this effect is mediated by the epidermal growth factor/phosphatidylinositol 3'-kinase/protein kinase B pathway [32]. In two studies it was shown that hypoxia downregulates ER in breast cancer cell lines [33,34]. More studies are therefore merited to investigate the interaction between ER and HIF-1.

Most knowledge about the interaction between HIF-1 and the cell cycle has been gathered around p53. Some of this interplay between p53 and HIF-1 was defined by An and colleagues [35], who showed that during hypoxia p53 could not stabilize without the presence of HIF-1 $\alpha$. Even a direct association between p53 and HIF- $1 \alpha$ was shown by co-immunoprecipitation in hypoxic cells. Subsequently, it was shown that p53 depends on HIF-1 $\alpha$ when it initiates apoptosis during hypoxia [21]. In contrast, Ravi and colleagues [8] showed that the concentration of HIF-1 $\alpha$ increased when no p53 was present in tumor cells that responded to hypoxia. HIF-1 and p53 can therefore be seen as competitors because both are upregulated by hypoxia. Whereas HIF-1 maintains homeostasis, p53 is known to induce apoptosis. However, HIF-1 might also induce apoptosis in concert with p53 [36] and through NIP3 [37]. Other factors influencing the balance between p53 and HIF-1 are competition for the cofactor p300 [38] and MDM-2 (murine double minute-2) degradation of HIF$1 \alpha$ through p53 [8]. Thus, a loss of wild-type p53 might be associated with increased tumor growth during hypoxia because of diminished apoptosis and augmented HIF-1induced transcriptional activation of VEGF. Indeed, the positive association between VEGF and the accumulation of p53, which is associated with p53 mutation, has been noted in breast cancer [39].

In the present study we found a positive association between the accumulation of p53 with HIF- $1 \alpha$ and that of p53 with VEGF (the positive association of HIF-1 $\alpha$ and VEGF has been described elsewhere [11]). The p53/HIF1 data are in concordance with those of Zhong and colleagues [22], who noted this association in a mixed group of colon and breast cancer patients. In contrast, in lymph node-positive breast cancer and epithelial ovarian cancer no relation between p53 and HIF- $1 \alpha$ was found $[31,40]$. Interestingly, we noticed that a classical association of HIF with proliferation and VEGF is true in wild-type p53 but not in the 'mutated' subgroup (assuming that more than 25\% nuclear p53 accumulation points to a p53 mutation). Thus, these data imply that HIF needs wild-type p53 to exert its downstream effects.

Combined high expression of p21 and cyclin $D_{1}$ was positively associated with high differentiation and low proliferation in various carcinomas including breast cancer $[29,41]$. Interestingly, in this study, increased concentrations of cyclin $D_{1}$ corresponded to high concentrations of $\mathrm{p} 21$ (as previously [29]), but not of HIF-1 $\alpha$. Many investigators have searched for an explanation of why cyclin $D_{1}$ becomes upregulated in breast cancer. The most plausible explanation is the assumption that an amplification or translocation of the cyclin $D_{1}$ gene is responsible, but other mechanisms also seem to be involved because of the low incidence of cyclin $D_{1}$ amplification. It has been shown that cyclin $D_{1}$ exerts the effects of ER [42], confirming the importance of cyclin $D_{1}$ in breast cancer. The results reported here might provide circumstantial evidence that upregulation of cyclin $D_{1}$ might be caused indirectly either by hypoxia or oncogenes that can stimulate HIF-1 and thereby p21. In fact, some specific $\mathrm{pVHL}$-deficient renal cell carcinoma cell lines showed such an association, although no feasible mechanism was described [43].

BCL-2 is known as an inhibitor of apoptosis. In this study we found an inverse association between HIF- $1 \alpha$ and BCL2. This is in contradiction of an earlier study on melanoma cell lines that showed that BCL-2 augments the angiogenic potential of HIF-1 by means of increased VEGF transcription and prolonged VEGF mRNA stabilization [44]. How- 
Table 7

\begin{tabular}{|c|c|c|c|c|c|c|c|}
\hline \multirow[t]{3}{*}{ Protein } & \multirow[t]{3}{*}{ Cutoff value } & \multicolumn{3}{|c|}{ Estrogen receptor-positive } & \multicolumn{3}{|c|}{ Estrogen receptor-negative } \\
\hline & & \multicolumn{2}{|c|}{ HIF-1 $\alpha$} & \multirow[t]{2}{*}{$P\left(\chi^{2}\right)$} & \multicolumn{2}{|c|}{ HIF-1 $\alpha$} & \multirow[t]{2}{*}{$P\left(\chi^{2}\right)$} \\
\hline & & $<5 \%$ & $\geq 5 \%$ & & $<5 \%$ & $\geq 5 \%$ & \\
\hline \multirow[t]{2}{*}{ Ki-67 } & $\leq 10 \%$ & 20 & 5 & 0.730 & 24 & 6 & 0.002 \\
\hline & $>10 \%$ & 15 & 6 & & 24 & 29 & \\
\hline \multirow[t]{2}{*}{ Cyclin A } & $\leq 10 \%$ & 24 & 7 & 0.717 & 28 & 9 & 0.003 \\
\hline & $>10 \%$ & 10 & 4 & & 20 & 26 & \\
\hline \multirow[t]{2}{*}{ Cyclin $D_{1}$} & $\leq 10 \%$ & 22 & 7 & 0.100 & 45 & 32 & 0.693 \\
\hline & $>10 \%$ & 13 & 4 & & 3 & 3 & \\
\hline \multirow[t]{2}{*}{ p21 } & $\leq 10 \%$ & 29 & 5 & 0.022 & 46 & 31 & 0.235 \\
\hline & $>10 \%$ & 6 & 6 & & 2 & 4 & \\
\hline \multirow[t]{2}{*}{ p53 } & $\leq 25 \%$ & 29 & 7 & 0.175 & 39 & 18 & 0.008 \\
\hline & $>25 \%$ & 6 & 4 & & 9 & 17 & \\
\hline \multirow[t]{3}{*}{$\mathrm{Bcl}-2$} & Negative & 0 & 0 & 0.477 & 4 & 5 & 0.141 \\
\hline & Moderate & 11 & 5 & & 18 & 18 & \\
\hline & Strong & 24 & 6 & & 26 & 11 & \\
\hline \multirow[t]{2}{*}{ VEGF } & Weak & 8 & 2 & 1.00 & 18 & 3 & 0.003 \\
\hline & Strong & 27 & 9 & & 30 & 32 & \\
\hline \multirow[t]{2}{*}{ HER-2/neu } & Negative & 33 & 8 & 0.080 & 43 & 23 & 0.008 \\
\hline & Positive & 2 & 3 & & 5 & 12 & \\
\hline
\end{tabular}

aFisher Exact Test when appropriate. HIF, hypoxia-inducible factor; VEGF, vascular endothelial growth factor.

ever, another paper suggested that VEGF itself stimulated BCL-2 expression in breast cancer [45]. Meanwhile, loss of $B C L-2$ fits the model in which upregulation of HIF- $\alpha$ is associated with breast cancer aggressiveness, because a loss of BCL-2 is associated with tumor aggressiveness [46]. We described previously that the rate of apoptosis and the concentrations of HIF- $1 \alpha$ are both increased in aggressive breast cancers [47]. This could be an epigenetic phenomenon, but other studies do indeed point to a direct apoptotic effect of HIF-1 when the cell loses control of homeostasis despite HIF-1 activation [48].

\section{Conclusion}

HIF- $1 \alpha$ overexpression is associated with increased proliferation, which might explain the adverse prognostic impact of increased concentrations of HIF-1 $\alpha$ in invasive breast cancer. In ER-positive tumors HIF-1 $\alpha$ is associated with p21, but not with proliferation. This shows the importance of further functional analysis to unravel the role of HIF-1 in late cell cycle progression, and the link between HIF-1, p21, and ER.

\section{Competing interests}

None declared.

\section{Authors' contributions}

$\mathrm{RB}$ was responsible for generating the hypothesis, collecting patient material, immunostaining, statistics, and writing the manuscript. PJvD was responsible for generating the hypothesis, classification of immunostaining, and correcting the manuscript. PvdG was responsible for immunostaining and correcting the manuscript. AS and AEG were responsible for generating the hypothesis and correcting the manuscript. EvdW was the study director, and was responsible for generating the hypothesis and correcting the manuscript.

\section{Acknowledgements}

We thank Wim Vos for help with immunostaining. This work was supported by unrestricted research support from the AEGON International Scholarship in Oncology (RB, PvdG, AS, AEG).

\section{References}

1. Semenza GL, Wang GL: A nuclear factor induced by hypoxia via de novo protein synthesis binds to the human erythropoietin gene enhancer at a site required for transcriptional activation. Mol Cell Biol 1992, 12:5447-5454. 
2. Jiang BH, Rue E, Wang GL, Roe R, Semenza GL: Dimerization, DNA binding, and transactivation properties of hypoxia-inducible factor 1. J Biol Chem 1996, 271:17771-17778.

3. Huang LE, Arany Z, Livingston DM, Bunn HF: Activation of hypoxia-inducible transcription factor depends primarily upon redox-sensitive stabilization of its alpha subunit. $J \mathrm{Biol}$ Chem 1996, 271:32253-32259.

4. Jiang BH, Semenza GL, Bauer C, Marti HH: Hypoxia-inducible factor 1 levels vary exponentially over a physiologically relevant range of $\mathrm{O}_{2}$ tension. $A m J$ Physiol 1996, 271:C1172-C1180.

5. Semenza GL: Regulation of mammalian $\mathrm{O}_{2}$ homeostasis by hypoxia-inducible factor 1. Annu Rev Cell Dev Biol 1999, 15:551-578.

6. Ratcliffe PJ, O'Rourke JF, Maxwell PH, Pugh CW: Oxygen sensing, hypoxia-inducible factor-1 and the regulation of mammalian gene expression. J Exp Biol 1998, 201:1153-1162.

7. Zundel W, Schindler C, Haas-Kogan D, Koong A, Kaper F, Chen E, Gottschalk AR, Ryan HE, Johnson RS, Jefferson AB, Stokoe D, Giaccia AJ: Loss of PTEN facilitates HIF-1-mediated gene expression. Genes Dev 2000, 14:391-396.

8. Ravi R, Mookerjee B, Bhujwalla ZM, Sutter $\mathrm{CH}$, Artemov D, Zeng Q, Dillehay LE, Madan A, Semenza GL, Bedi A: Regulation of tumor angiogenesis by p53-induced degradation of hypoxiainducible factor $1 \alpha$. Genes Dev 2000, 14:34-44.

9. Laughner E, Taghavi P, Chiles K, Mahon PC, Semenza GL: Her2 (neu) signaling increases the rate of hypoxia-inducible factor $1 \alpha($ hif-1 $\alpha)$ synthesis: novel mechanism for hif-1-mediated vascular endothelial growth factor expression. Mol Cell Biol 2001, 21:3995-4004.

10. Bos R, Zhong H, Hanrahan CF, Mommers EC, Semenza GL, Pinedo HM, Abeloff MD, Simons JW, van Diest PJ, van der Wall E: Levels of hypoxia-inducible factor- $1 \alpha$ during breast carcinogenesis. J Natl Cancer Inst 2001, 93:309-314.

11. Bos R, van der Groep P, Greijer AE, Shvarts A, Meijer S, Pinedo $H M$, Semenza GL, van Diest PJ, van der Wall E: Levels of hypoxia-inducible factor- $1 \alpha$ independently predict prognosis in patients with lymph node negative breast carcinoma. Cancer 2003, 97:1573-1581.

12. van Diest PJ, Baak JP: The morphometric prognostic index is the strongest prognosticator in premenopausal lymph nodenegative and lymph node-positive breast cancer patients. Hum Pathol 1991, 22:326-330.

13. Elston CW, Ellis IO: Pathological prognostic factors in breast cancer. I. The value of histological grade in breast cancer: experience from a large study with long-term follow-up. Histopathology 1991, 19:403-410.

14. van Diest $\mathrm{PJ}$ : No consent should be needed for using leftover body material for scientific purposes. BMJ 2002, 325:648-651.

15. Bobrow MN, Litt GJ, Shaughnessy KJ, Mayer PC, Conlon J: The use of catalyzed reporter deposition as a means of signal amplification in a variety of formats. J Immunol Methods 1992, 150:145-149.

16. Mommers EC, Leonhart AM, Falix F, Michalides R, Meijer CJ, Baak JP, Diest PJ: Similarity in expression of cell cycle proteins between in situ and invasive ductal breast lesions of same differentiation grade. J Pathol 2001, 194:327-333.

17. Blomberg I, Hoffmann I: Ectopic expression of Cdc25A accelerates the $G_{1} / S$ transition and leads to premature activation of cycl. Mol Cell Biol 1999, 19:6183-6194.

18. Michalides R, van Tinteren $H$, Balkenende A, Vermorken JB, Benraadt J, Huldij J, van Diest P: Cyclin A is a prognostic indicator in early stage breast cancer with and without tamoxifen treatment. Br J Cancer 2002, 86:402-408.

19. Bukholm IR, Bukholm G, Nesland JM: Over-expression of cyclin $A$ is highly associated with early relapse and reduced survival in patients with primary breast carcinomas. Int J Cancer 2001, 93:283-287.

20. van Diest PJ, Brugal G, Baak JP: Proliferation markers in tumours: interpretation and clinical value. J Clin Pathol 1998, 51:716-724.

21. Carmeliet $P$, Dor $Y$, Herbert JM, Fukumura $D$, Brusselmans $K$, Dewerchin M, Neeman M, Bono F, Abramovitch R, Maxwell P, Koch CJ, Ratcliffe P, Moons L, Jain RK, Collen D, Keshert E, Keshet E: Role of HIF-1 $\alpha$ in hypoxia-mediated apoptosis, cell proliferation and tumour angiogenesis. Nature 1998, 394:485-490.
22. Zhong $\mathrm{H}$, De Marzo AM, Laughner E, Lim M, Hilton DA, Zagzag D, Buechler P, Isaacs WB, Semenza GL, Simons JW: Overexpression of hypoxia-inducible factor $1 \alpha$ in common human cancers and their metastases. Cancer Res 1999, 59:5830-5835.

23. Bos R, van Diest PJ, van der GP, Greijer AE, Hermsen MA, Heijnen I, Meijer GA, Baak JP, Pinedo HM, van der WE, Shvarts A: Protein expression of B-cell lymphoma gene 6 (BCL-6) in invasive breast cancer is associated with cyclin D1 and hypoxia-inducible factor-1 $\alpha$ (HIF-1 $\alpha$ ). Oncogene 2003, 22:8948-8951.

24. Feldser D, Agani F, lyer NV, Pak B, Ferreira G, Semenza GL: Reciprocal positive regulation of hypoxia-inducible factor $1 \alpha$ and insulin-like growth factor 2. Cancer Res 1999, 59:3915-3918.

25. Maxwell PH, Wiesener MS, Chang GW, Clifford SC, Vaux EC, Cockman ME, Wykoff CC, Pugh CW, Maher ER, Ratcliffe PJ: The tumour suppressor protein VHL targets hypoxia-inducible factors for oxygen-dependent proteolysis. Nature 1999, 399:271-275.

26. Zhong $\mathrm{H}$, Chiles $\mathrm{K}$, Feldser D, Laughner E, Hanrahan C, Georgescu MM, Simons JW, Semenza GL: Modulation of hypoxiainducible factor $1 \alpha$ expression by the epidermal growth factor/phosphatidylinositol 3-kinase/PTEN/AKT/FRAP pathway in human prostate cancer cells: implications for tumor angiogenesis and therapeutics. Cancer Res 2000, 60:1541-1545.

27. Rose F, Grimminger F, Appel J, Heller M, Pies V, Weissmann N, Fink L, Schmidt S, Krick S, Camenisch G, Gassmann M, Seeger W, Hanze J: Hypoxic pulmonary artery fibroblasts trigger proliferation of vascular smooth muscle cells: role of hypoxiainducible transcription factors. FASEB J 2002, 16:1660-1661.

28. Goda N, Ryan HE, Khadivi B, McNulty W, Rickert RC, Johnson RS: Hypoxia-inducible factor $1 \alpha$ is essential for cell cycle arrest during hypoxia. Mol Cell Biol 2003, 23:359-369.

29. de Jong JS, van Diest PJ, Michalides RJ, Baak JP: Concerted overexpression of the genes encoding p21 and cyclin D1 is associated with growth inhibition and differentiation in various carcinomas. Mol Pathol 1999, 52:78-83.

30. Sivridis E, Giatromanolaki A, Gatter KC, Harris AL, Koukourakis MI: Association of hypoxia-inducible factors $1 \alpha$ and $2 \alpha$ with activated angiogenic pathways and prognosis in patients with endometrial carcinoma. Cancer 2002, 95:1055-1063.

31. Schindl $M$, Schoppmann SF, Samonigg $H$, Hausmaninger $H$, Kwasny W, Gnant M, Jakesz R, Kubista E, Birner P, Oberhuber G: Overexpression of hypoxia-inducible factor $1 \alpha$ is associated with an unfavorable prognosis in lymph node-positive breast cancer. Clin Cancer Res 2002, 8:1831-1837.

32. Mabjeesh NJ, Willard MT, Frederickson CE, Zhong H, Simons JW: Androgens stimulate hypoxia-inducible factor 1 activation via autocrine loop of tyrosine kinase receptor/phosphatidylinositol 3'-kinase/protein kinase B in prostate cancer cells. Clin Cancer Res 2003, 9:2416-2425.

33. Helczynska K, Kronblad A, Jogi A, Nilsson E, Beckman S, Landberg G, Pahlman S: Hypoxia promotes a dedifferentiated phenotype in ductal breast carcinoma in situ. Cancer Res 2003 , 63:1441-1444.

34. Stoner M, Saville B, Wormke M, Dean D, Burghardt R, Safe S: Hypoxia induces proteasome-dependent degradation of estrogen receptor alpha in ZR-75 breast cancer cells. $\mathrm{Mol}$ Endocrinol 2002, 16:2231-2242.

35. An WG, Kanekal M, Simon MC, Maltepe E, Blagosklonny MV, Neckers LM: Stabilization of wild-type 053 by hypoxia-inducible factor $1 \alpha$. Nature 1998, 392:405-408.

36. Piret JP, Mottet D, Raes M, Michiels C: Is HIF- $1 \alpha$ a pro- or an anti-apoptotic protein? Biochem Pharmaco/ 2002, 64:889-892.

37. Bruick RK: Expression of the gene encoding the proapoptotic Nip3 protein is induced by hypoxia. Proc Natl Acad Sci USA 2000, 97:9082-9087.

38. Blagosklonny MV, An WG, Romanova LY, Trepel J, Fojo T, Neckers L: p53 inhibits hypoxia-inducible factor-stimulated transcription. J Biol Chem 1998, 273:11995-11998.

39. Linderholm B, Lindh B, Tavelin B, Grankvist K, Henriksson R: p53 and vascular-endothelial-growth-factor (VEGF) expression predicts outcome in 833 patients with primary breast carcinoma. Int J Cancer 2000, 89:51-62.

40. Birner P, Schindl M, Obermair A, Breitenecker G, Oberhuber G: Expression of hypoxia-inducible factor $1 \alpha$ in epithelial ovarian tumors: its impact on prognosis and on response to chemotherapy. Clin Cancer Res 2001, 7:1661-1668. 
41. van Diest PJ, Michalides RJ, Jannink L, van d V, Peterse HL, de Jong JS, Meijer CJ, Baak JP: Cyclin D1 expression in invasive breast cancer. Correlations and prognostic value. Am J Pathol 1997, 150:705-711.

42. Zwijsen RM, Wientjens E, Klompmaker R, van der SJ, Bernards R, Michalides RJ: CDK-independent activation of estrogen receptor by cyclin D1. Cell 1997, 88:405-415.

43. Bindra RS, Vasselli JR, Stearman R, Linehan WM, Klausner RD: VHL-mediated hypoxia regulation of cyclin D1 in renal carcinoma cells. Cancer Res 2002, 62:3014-3019.

44. lervolino A, Trisciuoglio D, Ribatti D, Candiloro A, Biroccio A, Zupi $G$, Del Bufalo D: Bcl-2 overexpression in human melanoma cells increases angiogenesis through VEGF mRNA stabilization and HIF-1-mediated transcriptional activity. FASEB $J$ 2002, 16:1453-1455.

45. Pidgeon GP, Barr MP, Harmey JH, Foley DA, Bouchier-Hayes DJ: Vascular endothelial growth factor (VEGF) upregulates BCL-2 and inhibits apoptosis in human and murine mammary adenocarcinoma cells. Br J Cancer 2001, 85:273-278.

46. Villar E, Redondo M, Rodrigo I, Garcia J, Avila E, Matilla A: bcl-2 expression and apoptosis in primary and metastatic breast carcinomas. Tumour Biol 2001, 22:137-145.

47. Bos R, van Diest PJ, van der Wall E: Response: Re: levels of hypoxia-inducible factor-1 during breast carcinogenesis. J Natl Cancer Inst 2001, 93:1177-1177.

48. Sowter HM, Ratcliffe PJ, Watson P, Greenberg AH, Harris AL: HIF-1-dependent regulation of hypoxic induction of the cell death factors BNIP3 and NIX in human tumors. Cancer Res 2001, 61:6669-6673. 